\title{
Ixeris dentata (Thunb) Nakai attenuates cognitive impairment in MPTP-treated mouse model of Parkinson's disease
}

\author{
Sung-Gyu Lee ${ }^{1}$, Ki-Whan Kim², Hyun Kang ${ }^{1 *}$ \\ ${ }^{1}$ Department of Medical Laboratory Science, Dankook University, Cheonan-si, Chungnam, 31116, ${ }^{2}$ Department of R\&D Center, \\ C.L. Pharm Co., Ltd, \#1603-5 Seoul Forest IT Catsle, Gwangnaru-ro 132-gil, Seongdong-gu, Seoul, 04788, Republic of Korea \\ *For correspondence: Email: hkang@dankook.ac.kr; Tel: 82-41-550-3015
}

Sent for review: 5 September 2017

Revised accepted: 30 November 2017

\begin{abstract}
Purpose: To evaluate the cognition-enhancing effect of Ixeris dentata (Thunb) Nakai in a mouse model of Parkinson's disease (PD).

Methods: MPTP (1-methyl-4-phenyl-1,2,3,6-tetrahydropyridine)-induced mouse model of PD was used to evaluate the effect of Ixeris dentata (IDE) extract on the alteration of behavioral responses using rotarod and passive avoidance tests. The effect of IDE on oxidative stress levels were analyzed based on superoxide dismutase (SOD) and catalase (CAT) enzyme levels, and lipid peroxidation (LPO) in brain tissues.

Results: MPTP $(20 \mathrm{mg} / \mathrm{kg}$, ip)-induced mice resulted in a significant $(p<0.01)$ behavioral deficiencies in locomotor behavior (from $53.15 \pm 1.01$ to $23.56 \pm 1.04$ ) and cognitive functions (from $297 \pm 2.47$ to $201.17 \pm 3.23 \mathrm{~s})$ compared with their respective control groups. Administration of IDE (20, 40 and 80 $\mathrm{mg} / \mathrm{kg}, \mathrm{po})$ for three weeks significantly and dose-dependently improved $(p<0.001 \mathrm{at} 80 \mathrm{mg} / \mathrm{kg})$ locomotor and cognitive deficits in MPTP- treated mice. IDE treatment also significantly $(p<0.01$ at 80 $\mathrm{mg} / \mathrm{kg}$ ) inhibited decrease in superoxide dismutase and catalase enzyme activities, and lipid peroxides in MPTP-treated mice in brain tissues.

Conclusion: IDE exhibits good protection against MPTP-induced behavioral deficits via potential antioxidant defense mechanisms. Therefore, IDE could potentially be developed as a therapeutic approach for the treatment of neurodegenerative diseases.
\end{abstract}

Keywords: Ixeris dentata, Neurodegenerative disease, MPTP, Parkinson's disease, Oxidative stress

\begin{abstract}
This is an Open Access article that uses a funding model which does not charge readers or their institutions for access and distributed under the terms of the Creative Commons Attribution License (http://creativecommons.org/licenses/by/4.0) and the Budapest Open Access Initiative (http://www.budapestopenaccessinitiative.org/read), which permit unrestricted use, distribution, and reproduction in any medium, provided the original work is properly credited.
\end{abstract}

Tropical Journal of Pharmaceutical Research is indexed by Science Citation Index (SciSearch), Scopus, International Pharmaceutical Abstract, Chemical Abstracts, Embase, Index Copernicus, EBSCO, African Index Medicus, JournalSeek, Journal Citation Reports/Science Edition, Directory of Open Access Journals (DOAJ), African Journal Online, Bioline International, Open-J-Gate and Pharmacy Abstracts

\section{INTRODUCTION}

Oxidative stress occurs as a result of discrepancy of free radical generation [1]. The brain is believed to be defenseless to oxidative damage highly metabolic rate and relatively low cellular regeneration ability [2]. ROS production is regulated by NADPH oxidase and nitric oxide synthase in the neuropathological condition in brain. In the MPTP model of Parkinson's disease (PD) are major sources of ROS production and mediates dopaminergic neuronal death in 
substantia nigra $[3,4]$.

The neurotoxin, MPTP, causes clinical and chemical alterations that occur in PD [5,6]. After administration, MPTP rapidly passes through the blood brain barrier and is altered to its active form, 1-methyl-4-phenylpyridinium (MPP+), by a reactive oxidizing enzyme in astrocytes [7]. The oxidative stress occurs by MPP + consequently results in the peroxidation of molecules, resulting in neuronal cell death $[8,9]$.

Cognition in a broad sense means the ability of the brain to encode, store and rescue information [10]. The hippocampus contains the neural circuitry key for cognitive functions such as learning and memory, and intellectual features of mental functioning [11]. Cognitive dysfunction can negatively affect learning and memory skills of individuals leading to the pathogenesis of neurodegenerative disorders [12].

Ixeris dentata var. albiflora Nakai, from the family Astaraceae, is a medicinal herbal plant used traditionally in Asian countries to treat stomach upsets, diabetes, tumors and liver diseases $[13,14]$ Pharmacologically, I. dentata has been reported to possess anti-mutagenic, anti-cancer, hypoglycemic, hypocholesterolemic and oxidative stress inhibiting properties [15-17]. However, the cognitive-enhancing effect of $l$. dentata in MPTP mouse models of Parkinson's disease conditions has not been studied.

In the present study, we sought to investigate the cognitive-enhancing effects of IDE in MPTP mouse models of Parkinson's disease, as well as elucidate the possible antioxidant defense of IDE.

\section{EXPERIMENTAL}

\section{Chemicals and reagents}

All chemicals were purchased from Sigma (St Louis, MO, USA) and were of analytical grade. Stock solutions of all chemicals were prepared in cell culture grade distilled water and the dilutions prepared fresh on the day of the experiment.

\section{Plant material and preparation of $\mathbf{l}$. dentata extract}

I. dentata collected during the month of August to September from a local herbal market, Seoul, Republic of Korea. To obtain the I. dentata extract, the plant material was washed to remove debris and then air-dried for two days. The dried roots were then pulverized into powder using an electric blender (model 4250, Braun, Germany). Fifty grams of the powdered roots were extracted with three volumes of $80 \%$ ethanol with mixing at room temperature for $24 \mathrm{~h}$. The extract was filtered and lyophilized to obtain ethanol extract concentrate $(\mathrm{EtOH})$ of $I$. dentata (yield: $17.5 \mathrm{~g}$ ). The $\mathrm{EtOH}$ extract of $I$. dentata root extract $(10 \mathrm{~g})$ was re-suspended in distilled water:EtOH (9:1, $\mathrm{v} / \mathrm{v}$ ) and partitioned in turn with $n$-hexane, chloroform, ethylacetate (EA) and $n$-butanol solvents to obtain a final yield of $0.48,0.10,0.47$ and $1.27 \%$, respectively.

The EA fraction of I. dentata (IDE) extract with strong antioxidant property in our preliminary evaluation was used for further studies. The IDE extract was dissolved in sterile distilled water, filtered through $0.22 \mu \mathrm{m}$ syringe filters and stored at $-20{ }^{\circ} \mathrm{C}[18]$

Male C57BL/6 mice (22 - $25 \mathrm{~g}$, 8-weeks-old) were obtained from Orient Bio Co. (Seoul, Korea). They were housed in groups of five under standard conditions of $22 \pm 2{ }^{\circ} \mathrm{C}, 55 \%$ relative humidity, and 12/12 $\mathrm{h}$ light/dark cycle with food and water ad libitum. All animal experiments carried out according to the guidelines of Principles of Laboratory Animal Care [20] and were approved by Dankook University Institutional Animal Care and Use Committee (no. DKU-16-028).

\section{Experimental design}

The mice were separated into five groups $(\mathrm{n}=$ 15), i.e., vehicle, MPTP (1-methyl-4-phenyl1,2,3,6-tetrahydropyridine, $20 \mathrm{mg} / \mathrm{kg}$ ), MPTP + IDE $20 \mathrm{mg} / \mathrm{kg}$, MPTP + IDE $40 \mathrm{mg} / \mathrm{kg}$ and MPTP + IDE $80 \mathrm{mg} / \mathrm{kg}$. MPTP $20 \mathrm{mg} / \mathrm{kg}$ (i.p.) was administered along with probenecid $200 \mathrm{mg} / \mathrm{kg}$ (i.p.) for five successive days to induce chronic Parkinsonian symptoms in mice as described previously [20]. Different doses of IDE (20, 40 and $80 \mathrm{mg} / \mathrm{kg}$ ) were prepared freshly in distilled water and administered on day 1 ( $1 \mathrm{~h}$ prior to MPTP administration) and continued up to 21 days through oral gavage (p.o.).

Locomotor behavioral paradigm was evaluated during the course of MPTP administration (Day 7) and also at the last phase of the study (Day 20). Cognitive paradigm using passive avoidance examination was evaluated on day 20 (acquisition) and day 21 (retention). The protocol for perfusion and tissue processing was performed as described previously [20]. All the brain tissues were rinsed in ice-cold isotonic saline, homogenized with $1 \mathrm{~mL}$ of ice-cold $0.1 \mathrm{M}$ PBS ( $\mathrm{pH}$ 7.4) and centrifugation at $4000 \mathrm{rpm}$ for $10 \mathrm{~min}$. Aliquots of homogenates were used for estimation of superoxide dismutase (SOD), catalase (CAT) and lipid peroxide (LPO) levels. 


\section{Rotarod test}

In rotarod test (ROTA-ROD, Varese, Italy), the beam revolves around its longitudinal axis and the animal walks or runs forward in synchrony. After adaptation for $5 \mathrm{~min}$, the mice were placed on a horizontal plastic rod rotating at a speed of $10 \mathrm{rpm}$ for $10 \mathrm{~min}$. The period (s) that each experimental mouse was able to maintain its balance walking on the top of the rod was measured.

\section{Passive avoidance test}

A step through type passive avoidance test apparatus (GEMINI, model PACS-30, San Diego instruments Int., USA) was used to evaluate the effects of extract on learning and memory as described previously [21]. The shuttle box is divided into two chambers of same size $(23.5 \mathrm{~cm}$ $\times 15.5 \mathrm{~cm} \times 15.5 \mathrm{~cm}$ ) separated by a guillotine door. Mice were placed initially in the light chamber with the door open. They displayed exploratory behavior, and then entered the dark chamber. Upon entering the dark compartment, the door closed automatically. Training was continued until the mouse entered the dark chamber within $20 \mathrm{~s}$ (training trial). Twenty four hours after the training trial, the mouse was placed in the illuminated chamber. When the mice entered the dark chamber, electric foot shock $(1 \mathrm{~mA})$ was delivered for $3 \mathrm{~s}$ through the grid floor and the door was closed automatically (acquisition trial). The mouse was again placed in the dark chamber, $24 \mathrm{~h}$ after the acquisition trial and the latency time to enter the dark chamber was measured for $300 \mathrm{~s}$ for the retention trial. If the mice did not enter the dark chamber within the cutoff time (300 s), it was assigned a latency value of $300 \mathrm{~s}$.

\section{SOD assay}

The ability to scavenge the superoxide radicals in the brain homogenate generated by autooxidation of pyrogallol in alkaline medium was calculated. Each $3 \mathrm{~mL}$ reaction mixture contained $2.8 \mathrm{~mL}$ of potassium phosphate buffer $(0.1 \mathrm{M}, \mathrm{pH}$ 7.4), $0.1 \mathrm{~mL}$ tissue homogenate and $0.1 \mathrm{~mL}$ pyrogallol solution (2.6 mM in $10 \mathrm{mM} \mathrm{HCl}$ ). Increase in the absorbance at $325 \mathrm{~nm}$ was recorded by spectrophotometer for a period of 5 min at 30 s interval (UV-1601, Shimadzu).

\section{CAT assay}

CAT activity was assessed by the method described previously [16]. Briefly, catalase activity is measured by the decomposition of hydrogen peroxide $\left(\mathrm{H}_{2} \mathrm{O}_{2}\right)$ or by liberation of oxygen $\left(\mathrm{O}_{2}\right)$. The decrease in the absorbance by $\mathrm{H}_{2} \mathrm{O}_{2}$ as a function of time is used to follow the catalase-peroxide reaction. Reaction solution was $2.9 \mathrm{~mL}$ of $10 \mathrm{mM} \mathrm{H}_{2} \mathrm{O}_{2}$ in $50 \mu \mathrm{M}$ potassium phosphate buffer $(\mathrm{pH} 7)$ and $0.1 \mathrm{~mL}$ of tissue homogenate. Decrease in the absorbance at 240 $\mathrm{nm}$ was recorded by spectrophotometer for $3 \mathrm{~min}$ (UV-1601, Shimadzu). The results were calculated as units of CAT activity per $\mathrm{mg}$ of protein.

\section{Lipid peroxidase assay}

The lipid peroxidase (LPO) content in the brain homogenate was determined by the spectrophotometric method as described previously [19]. Tissue homogenate $(0.2 \mathrm{~mL})$ was added to a mixture of $0.2 \mathrm{~mL}$ of $8.1 \%$ SDS, 1.5 $\mathrm{mL}$ of $20 \%$ acetic acid solution ( $\mathrm{pH} 3.5)$, and 1.5 $\mathrm{mL}$ of $0.8 \%$ aqueous solution of thiobarbituric acid (TBA). The final mixture volume was adjusted to $4.0 \mathrm{~mL}$ with distilled water, and then heated at $95{ }^{\circ} \mathrm{C}$ for $60 \mathrm{~min}$ in a water bath. After cooling, $1 \mathrm{~mL}$ of distilled water and $5.0 \mathrm{~mL}$ of the mixture of $n$-butanol and pyridine $(15: 1, \mathrm{v} / \mathrm{v})$ were added to the final reaction mixture and shaken vigorously. After centrifugation at $4000 \mathrm{rpm}$ for $10 \mathrm{~min}$, the absorbance of the organic layer was measured spectrophotometrically (UV-1601, Shimadzu) at $532 \mathrm{~nm}$. LPO was calculated for nanomoles of malondialdehyde (MDA) per mg of protein.

\section{Statistical analysis}

All data are expressed as mean \pm SEM. Statistical significance ( $p<0.05$ for all analyses) was assessed by ANOVA using Instat 3.05 (GraphPad, San Diego, CA), followed by Student-Newman-Keuls analysis.

\section{RESULTS}

\section{Effects of IDE extract on MPTP-induced locomotor impairment in mice}

As shown in Figure 1, MPTP significantly $(p<$ 0.01 ) impaired locomotor activity on day 7 (9.85 $\pm 1.35)$ and day $21(23.56 \pm 1.04)$. Administration of IDE extract at various doses $(20,40$ and 80 $\mathrm{mg} / \mathrm{kg}$ ) did not influence the MPTP-induced locomotor deficits on day 7. However, on day 21 IDE extract $(20,40$ and $80 \mathrm{mg} / \mathrm{kg}$ ) significantly attenuated the decreased locomotor activity in a dose-dependent manner (33.32 $\pm 0.91 ; p<0.05$, 


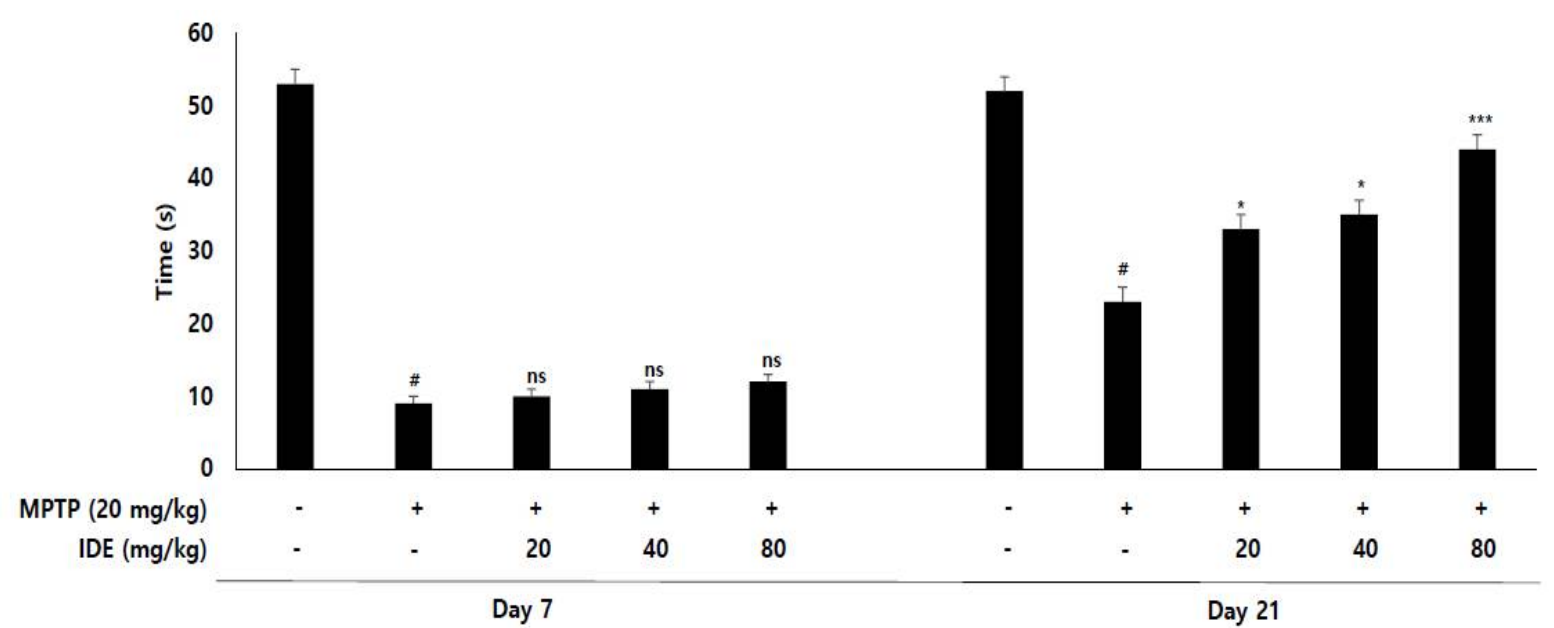

Figure 1: Effect of IDE extract on MPTP- treated locomotor impairment in mice. Rotarod performance in different experimental groups on day 7 and day 21 was shown; \#p $<0.001$ compared with their respective untreated groups. NS: Not significant; ${ }^{*} p<0.05$ and ${ }^{* * *} p<0.001$ compared with MPTP-induced group. Data expressed as mean \pm SEM $(n=5)$; MPTP: 1-methyl-4-phenyl-1, 2, 3, 6-tetrahydropyridine; IDE: Ixeris dentata extract

$35.26 \pm 1.51 ; p<0.05$ and $44.23 \pm 1.09 ; p<0.01$ at 20,40 and $80 \mathrm{mg} / \mathrm{kg}$, respectively).

\section{Effect of IDE extract on MPTP-induced passive avoidance in mice}

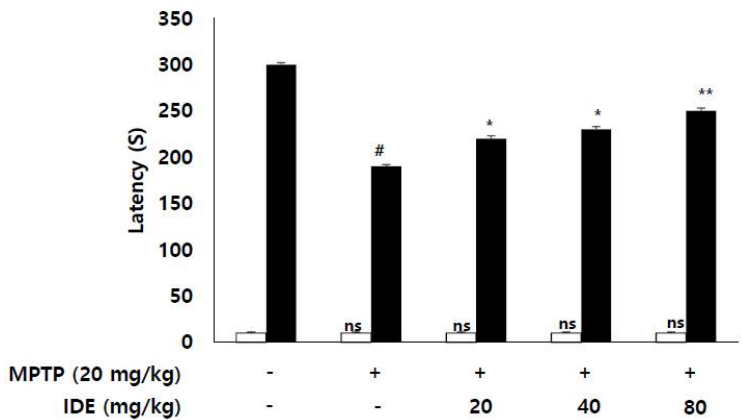

Figure 2: Effects of IDE extract on the MPTP- treated cognitive impairment in mice. Latency times (s) in acquisition (trial 1) was carried on day 21 and retention (Trial 2) was carried $24 \mathrm{~h}$ after trial 1 (Day 21). $\square$ : Acquisition, $\mathbf{~ : ~ R e t e n t i o n . ~ \# p ~}<0.001$ compared with untreated group. NS: Not significant. ${ }^{*} p<0.05$ and ${ }^{* *} p<0.01$ compared with MPTP-induced group. Data are expressed as mean \pm SEM $(n=5)$; MPTP: 1 methyl-4-phenyl-1,2,3,6-tetrahydropyridine; IDE: Ixeris dentata extract

As shown in Figure 2, no significant differences were observed in latency time in any group in the absence of the aversive foot-shock stimulus (acquisition trial). The latency time was significantly increased in retention trial $(297 \pm$ $2.47 \mathrm{~s})$ compared to acquisition trial (17.37 \pm $1.86 \mathrm{~s}$ ) in control trained group. In addition, the latency to enter the dark compartment was significantly decreased $24 \mathrm{~h}$ after foot shock in MPTP-induced mice compared with control mice (control mice: $297.5 \pm 2.47 \mathrm{~s}$; MPTP-induced mice: $201.217 \pm 3.23 \mathrm{~s}, \mathrm{p}<0.001$ vs. control mice). However, IDE extract treatment at the indicated doses $(20,40$ and $80 \mathrm{mg} / \mathrm{kg}$ ) significantly attenuated the decreased latency time $(230.54 \pm 6.52 \mathrm{~s} ; \mathrm{p}<0.05,238.84 \pm 7.78 \mathrm{~s}$; $\mathrm{p}<0.05$ and $258.15 \pm 7.42 \mathrm{~s} ; \mathrm{p}<0.01$ ) at 20,40 and $80 \mathrm{mg} / \mathrm{kg}$, respectively.

\section{Effect of IDE extract on antioxidant enzymes in brain tissue of MPTP-treated mice}

As shown in Figure 3, significant decrease in the activities of SOD and CAT was observed in MPTP-treated group $(p<0.001)$ when compared with their respective control groups (A and $B)$. Furthermore, LPO levels were significantly $(p<$ 0.001 ) increased in MPTP-induced group (C). However, IDE treated groups (20, 40 and 80 $\mathrm{mg} / \mathrm{kg}$ ) dose dependently attenuated these changes. Although $20 \mathrm{mg} / \mathrm{kg}$ dose of IDE did not show significant effect in altering the SOD and LPO activity, the effects were dose-dependent. The highest effect was observed at $80 \mathrm{mg} / \mathrm{kg}$ dose $(p<0.01)$.

\section{DISCUSSION}

The purpose of this study was to use the MPTPinduced mouse model to evaluate the effect of IDE on PD as well as examine its effect on the central neuropathological features of Parkinson's diseases. PD is a progressive neuronal cell death of dopaminergic neurons in substantia nigra and depletion of dopamine in the striatum, the site into which their nerve terminals project $[19,20]$. 

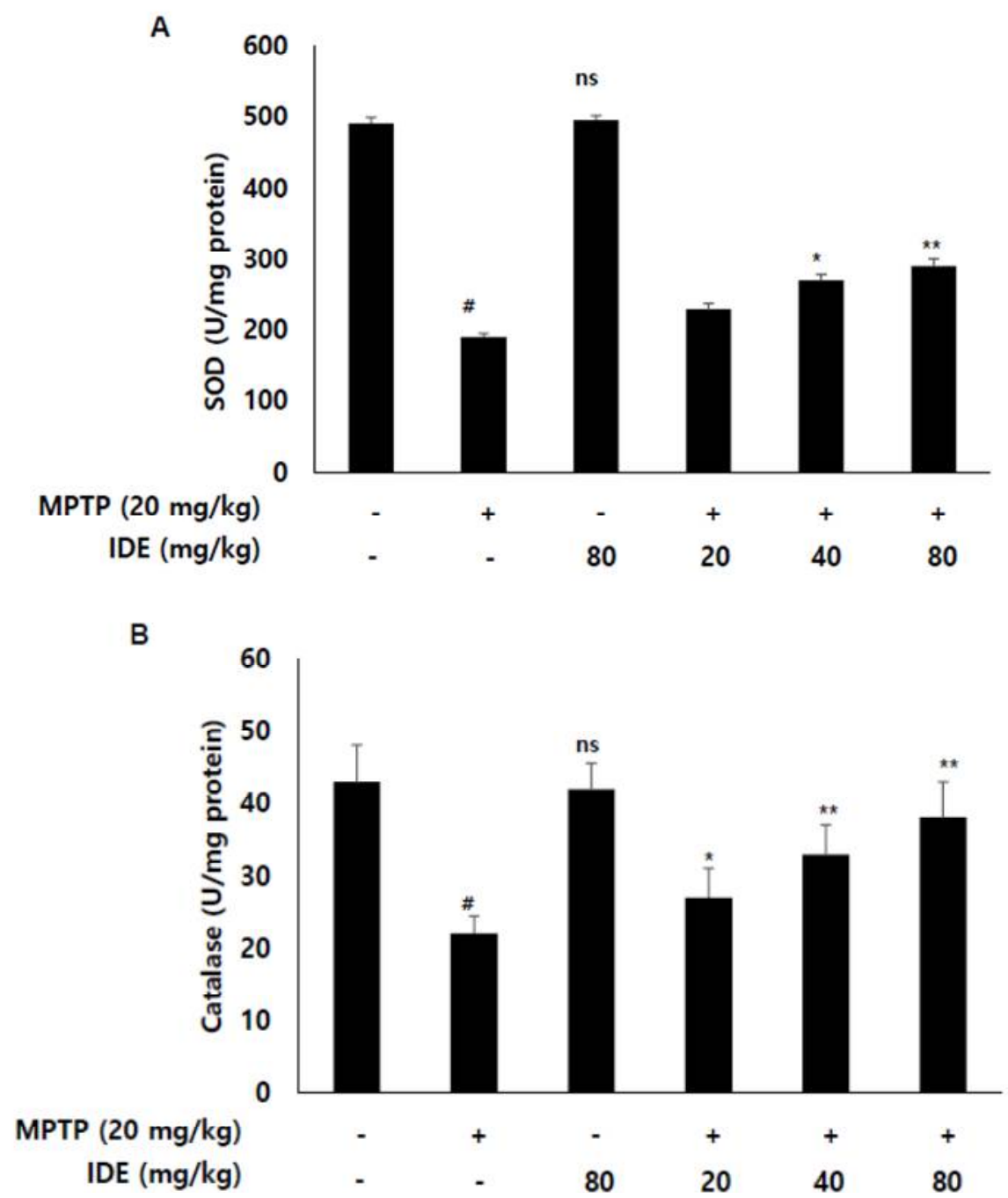

C

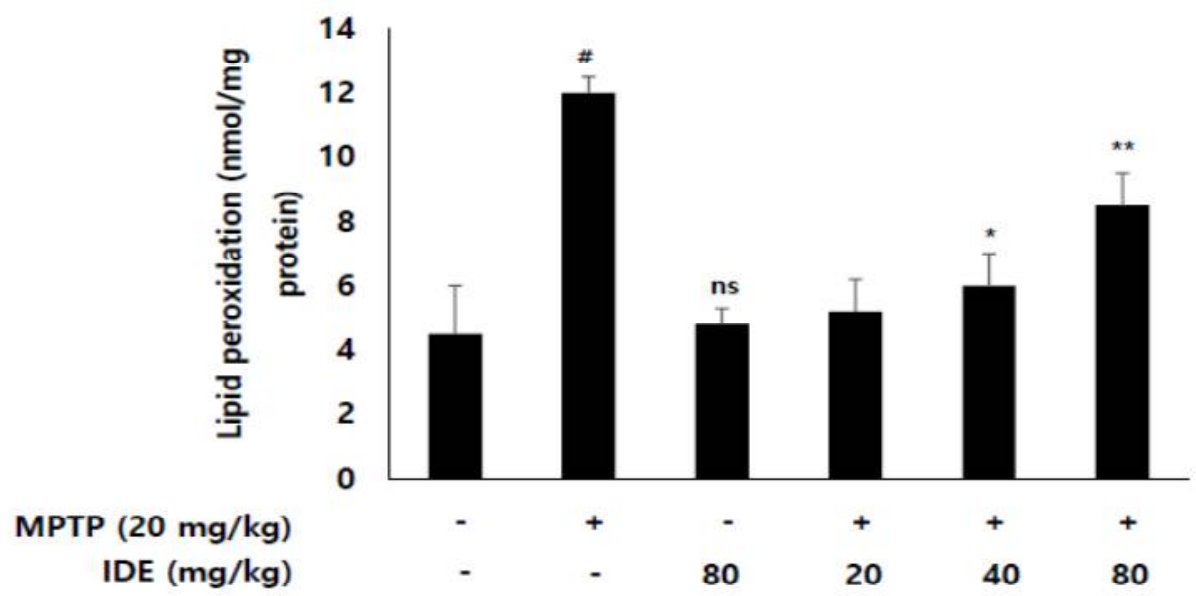

Figure 3: Effect of IDE extract on anti-oxidant enzyme levels in MPTP- treated mice. The antioxidant enzymes levels in different experimental groups were shown. A: Superoxide dismutase (SOD), B: catalase (CAT) and C: Lipid peroxides (LPO); \#p $<0.001$ compared with untreated group. ${ }^{*} p<0.05$, ${ }^{* *} p<0.01$ and ${ }^{* * *} p<$ 0.001 compared with MPTP-induced group. Data expressed as mean \pm SEM $(n=5)$; MPTP: 1-methyl-4-phenyl1,2,3,6-tetrahydropyridine; IDE: Ixeris dentata extract 
In the present study. IDE extract perhaps attenuated the cognitive and behavioral impairments in MPTP mouse models of Parkinson's disease. The enhanced cognitive and behavioral function exhibited by IDE extract treatment was strongly supported by reduced brain oxidative stress in MPTP-treated mice.

Rotarod test is widely used to confirm motor deficit in PD models [20] and our result also revealed motor deficit in MPTP-induced mice group. Locomotor dysfunction including tremors, rigidity and bradykinesia are a variety of clinical symptoms of neurodegenerative diseases [23]. Behavioral effects are intertwined with the degree of neuronal dysfunction, and its assessment is a more powerful endpoint in identifying neuroprotection. Locomotor data indicate that a low dose of MPTP (at least 20 $\mathrm{mg} / \mathrm{kg}$ ) can regulate locomotor ability down to the $18 \%$ of control.

The results from behavioral assessment based on rota rod test suggest that long term treatment of IDE extract improved muscular activity and locomotion. It is well known that MPTP-induction in non-human primates and mice develop cognitive deficits $[24,25]$. Therefore, testing the behavioral function provides a sensitive evaluation of the IDE's ability to provide neuroprotection of brain [26].

Treatment with IDE ameliorated decreases in retention latency time in the passive avoidance test in MPTP-treated mice given IDE. MPTPtreated mice significantly altered the cognitive performance with reduced performance in passive avoidance test. Mice administered 80 $\mathrm{mg} / \mathrm{kg}$ IDE extract showed a considerable improvement compared with lower doses (20 and $40 \mathrm{mg} / \mathrm{kg}$ ).

Oxidative stress in MPTP-treated mice was measured by determining the activity of SOD and CAT, and LPO levels in mouse brain tissue. IDE extract treatment improved the MPTP-induced reduction in the activities of antioxidant enzymes and resulted in reduced levels of oxidative stress. IDE extract effectively ameliorated antioxidant enzyme activities in MPTP treated animals especially at the dose of $80 \mathrm{mg} / \mathrm{kg}$. The antioxidant effects observed in this study are in concord with our previous work which found that IDE has the ability to scavenge free radicals [28]

In PD, the astrocytes are in their activated states in substantia nigra. MPTP administration in mice also leads to the activation of astrocytes in $\mathrm{SN}$ similar to PD $[29,30]$.
The major active constituent of IDE is approximately $4 \mathrm{mg}$ per $\mathrm{g}$ of caffeic acid $[31,32]$. Approximately 20 different types of sesquiterpene and polyphenol compounds have been isolated from IDE. It has been reported that its key compounds are luteolin, luteolin 7-Oglucuronide, caffeic acid, chlorogenic acid, and guaiane sesquiterpene lactones [33]. Among these main compounds, the inhibitory effects of tectroside, luteolin, quercitrin, and chlorogenic acidon allergic inflammation had already been reported [34,35]. The most important active components of IDE are phenolic constituents [36]. These compounds might act individually or in a synergistic mode in their neuroprotective effect in brain cell.

A variety of antioxidant supplements and phytochemical components might be helpful for preserving brain functions and prevention of neurodegenerative diseases [8]. Thus, IDE agents that scavenge free radicals and regulate oxidative defense mechanisms may have potentials in the alleviation of cognitive dysfunction seen in PD or other neurodegenerative diseases. In our previous work we presented data on the suppression of NF-KB activation pathways by IDE [19]. Further, the antioxidant actions of IDE might also be involved in affecting such potent antineuroinflammatory actions. Therefore, IDE can potentially be developed on a commercial level as a therapeutic raw material for the treatment of PD or other neurodegenerative diseases.

\section{CONCLUSION}

The findings of this study show that IDE exerts protective effects on the habit learning memory and spatial memory deficits in an MPTP-treated mice. Further, MPTP-induced alteration in antioxidative enzyme levels is reversed in mouse brain tissue treated with IDE. Regulation of antioxidant defense mechanisms by IDE is perhaps responsible for its neuroprotective effect in MPTP-treated mice. Further studies on a major active constituent of IDE and how it works in microglia cell may provide an insight into its molecular mechanism.

\section{DECLARATIONS}

\section{Acknowledgement}

This research was supported by Ministry of Trade, Industry \& Energy (MOTIE), Korea Institute for Advancement of Technology (KIAT) through Encouragement Program for The Industries of Economic Cooperation Region) 


\section{Conflict of interest}

No conflict of interest is associated with this work.

\section{Contribution of authors}

We declare that this work was done by the authors named in this article and all liabilities pertaining to claims relating to the content of this article will be borne by the authors.

\section{REFERENCES}

1. Teismann P, Tieu K, Cohen O, Choi DK, Wu DC, Marks $D$, Vila M, Jackson-Lewis V, Przedborski S. Pathogenic role of glial cells in Parkinson's disease. Mov Disord 2003; 18: 121-129

2. Wu DC, Teismann $P$, Tieu K, Vila M, Jackson-Lewis V, Ischiropoulos $H$, Przedborski S. NADPH oxidase mediates oxidative stress in the 1-methyl-4-phenyl164 1,2,3,6-tetrahydropyridine model of Parkinson's disease. Proc Natl Acad Sci USA 2003; 100: 6145-6150

3. Rodriguez-Pallares J, Parga JA, Munoz A, Rey P, Guerra MJ, Labandeira-Garcia JL. Mechanism of 6hydroxydopamine neurotoxicity: the role of NADPH oxidase and microglial activation in 6-hydroxydopamineinduced degeneration of dopaminergic neurons. J Neurochem 2007; 103: 145-156 5

4. Oyagi A, Oida $Y$, Hara $H$. "Protective effects of SUN N8075, a novel agent with antioxidant properties, in in vitro and in vivo models of Parkinson's disease," Brain Res 1996; 1214: 169-176

5. Langston JW, Ballard P, Tetrud JW, Irwin I. Chronic Parkinsonism in humans due to a product of meperidine-analog synthesis. Science 1983; 219: 979980

6. Przedborski S, Jackson-Lewis $V$, Naini AB, Jakowec $M$, Petzinger G, Miller R, Akram M. The parkinsonian toxin 1-methyl-4-phenyl-1,2,3,6-tetrahydropyridine (MPTP): a technical review of its utility and safety. $J$ Neurochem 2001; 76: 1265-1274

7. Przedborski S and Vila M: The 1-methyl-4-phenyl-1,2,3,6tetrahydropyridine mouse model. a tool to explore the pathogenesis of Parkinson's disease. Ann N Y Acad Sci 2003; 991:189-198

8. Blum D, Torch $S$, Lambeng N. "Molecular pathways involved in the neurotoxicity of 6-OHDA, dopamine and MPTP: contribution to the apoptotic theory in Parkinson's disease," Prog in Neurobiol 2001; 65: 135172

9. Meissner WG, Frasier M, Gasser T, Goetz CG, Lozano A, Piccini P. Priorities in Parkinson's disease research. Nat Rev 2011; 10: 377-393.

10. Hely MA, Morris JGL, Reid WGJ, Trafficante R. Sydney multicenter study of Parkinson's disease: Non-L-doparesponsive problems dominate at 15 years. 2005; Mov. Disord. 20: 190-199
11. Aarsland D, Bronnick K, Ehrt U, De Deyn PP, Tekin S, Emre M, Cummings JL. Neuropsychiatric symptoms in patients with Parkinson's disease and dementia: frequency, profile and associated care giver stress. J. Neurol. Neurosurg. Psychiatry 2007; 78: 36-42

12. Nostro A, Cellini L, Di Bartolomeo S, Di Campli E, Grande R, Cannatelli MA. Antibacterial effect of plant extracts against Helicobacter pylori. Phytother Res 2005; 19: 198-202.

13. Satyanarayana S, Sushruta K, Sarma GS, Srinivas N, Subba Raju GV. Antioxidant activity of the aqueous extracts of spicy food additives--evaluation and comparison with ascorbic acid in in-vitro systems. J Herb Pharmacother 2004; 4(2): 1-10.

14. Ahn E, Bang M, Song M. Cytotoxic and ACAT inhibitory sesquiterpene lactones fromthe root of Ixeris dentata forma albiflora. Arch Pharm Res 2006; 29: 937-941.

15. Hong S, Jeong D, Kim K, Hwang E. The Composition of the Root of Ixeris dentata var. albiflora Nakai. and Cell Viability and DPPH Radical Scavenging Activities of its Extract. Korean J Nutr 2010; 43: 105-113.

16. Kim MJ, Kim JS, Jeong DM, Ham SS, Yu CY. Effect of antioxidant, antimutagenicity and anticancer of root extract from Ixeris dentata Nakai. Korean J Medicinal Crop Sci 2002; 10: 222-229.

17. Choi JS, Chung HY, Young HS. A preliminary study on hypocholesterolemic and hypoglycemic activities of some medical plants. Korean J Phamacogn 1990; 21: 153-155

18. Lee SK, Kang H. Ixeris dentata (Thunb) Nakai Ethylacetate Extract Attenuates Sterol Regulatory Element-Binding Proteins-1C via AMP-Activated Protein Kinase Activation. Trop J Pharm Res 2016; 15: 453-459

19. The guidelines of Principles of Laboratory Animal Care, NIH publication 1985: 85: 23

20. Jackson-Lewis V, Przedborski S. Protocol for the MPTP mouse model of Parkinson's disease. Nat Protoc 2007; 2(1): 141-151.

21. Patil $S P$, Jain $P D$, Ghumatkar PJ, Tambe R, Sathaye $S$. Neuroprotective effect of metformin in MPTP-induced Parkinson's disease in mice. Neurosci 2014; 26; 277: 747-754

22. Moon M, Kim HG, Hwang L, Seo JH, Kim S, Hwang S, Kim S, Lee D, Chung $H$, Oh MS, et al. Neuroprotective effect of ghrelin in the 1-methyl-4-phenyl-1,2,3,6tetrahydropyridine mouse model of Parkinson's disease by blocking microglial activation. Neurotox Res 2009; 15: 332-347.

23. Jankovic J. Parkinson's disease: Clinical features and diagnosis. J Neurol Neurosurg Psychiat 2008; 79: 368376 .

24. Araki T, Mikami T, Tanji H, Matsubara M., Imai Y., Mizugaki $M$, Itoyama $Y$. Biochemical and immunohistological changes in the brain of 1-methyl-4phenyl-1,2,3,6-tetrahydropyridine (MPTP)-treated mouse. Eur J Pharm Sci, 2001; 12: 231-238.

25. Sriram K, Pai KS, Boyd, MR, Ravindranath V. Evidence for generation of oxidative stress in brain by MPTP: in 
vitro and in vivo studies in mice. Brain Res, 1997; 749: 44-52

26. Wang AL, Liou YM, Pawlak CR, Ho YJ. Involvement of NMDA receptors in both MPTP-induced neuroinflammation and deficits in episodic-like memory in Wistar rats. Behav. Brain Res. 2010; 208: 38-46

27. Dunlop BW, Nemeroff $C B$. The role of dopamine in the pathophysiology of depression. Arch. Gen. Psychiatry 2007; 64: 327-337

28. Faure A, Haberland U, Condé F, El-Massioui F. Lesion to the nigrostriatal dopamine system disrupts stimulusresponse habit formation, J. Neurosci. 2005; 25: 2771 2780

29. Ferro MM, Bellissimo MI, Anselmo-Franci JA, Angellucci MEM, Canteras NS, Cunha CD. Comparison of bilaterally 6-OHDA- and MPTP-lesioned rats as models of the early phase of Parkinson's disease: Histological, neurochemical, motor and memory alterations. J. Neurosci. Meth. 2005; 148: 78-87.

30. Perier C, Vila M. Mitochondrial biology and Parkinson's disease. Cold Spring Harb Perspect Med 2012; 4: 1-19.
31. Chung YC, Kim SR, Park JY, Chung ES, Park KW, Won SYFluoxetine prevents MPTP-induced loss of dopaminergic neurons by inhibiting microglial activation. Neuropharmacol 2011; 60: 963-974

32. Kang H. Anti-Neuroinflammatory Effects of Ixeris dentata Nakai against Lipopolysaccharide-Induced BV-2 Microglial Cells via Suppressing NF-KB Signaling. Trop J Pharm Res 2014; 13: 1629-1635

33. Kim DS, Ko JH, Jeon YD, Han YH, Kim HJ, Poudel A. Ixeris dentata NAKAI Reduces Clinical Score and HIF-1 Expression in Experimental Colitis in Mice. Evid Based Complement Alternat Med 2013; 67: 1281-1289

34. Cha MR, Choi YH, Choi CW, Yoo DS, Kim YS, Choi SU. New guaiane sesquiterpene lactones from Ixeris dentata. Planta Med 2011; 77: 380-382

35. Kim SB, Kang OH, Joung DK, Mun SH, Seo YS, Cha MR. Anti-inflammatory effects of tectroside on UVB induced HaCaT cells. Int $\mathrm{J} \mathrm{Mol} \mathrm{Med} \mathrm{2013;} \mathrm{31:} \mathrm{1471-}$ 1476. 